\title{
Delftia tsuruhatensis sp. nov., a terephthalate- assimilating bacterium isolated from activated sludge
}

Correspondence
Toru Shigematsu
shige@kumamoto-u.ac.jp

\author{
Toru Shigematsu, ${ }^{1}$ Kazuyo Yumihara, ${ }^{1,2}$ Yutaka Ueda, ${ }^{1}$ \\ Masaki Numaguchi, ${ }^{3}$ Shigeru Morimura ${ }^{1}$ and Kenji Kida ${ }^{1,3}$ \\ ${ }^{1,3}$ Department of Materials and Life Science, Graduate School of Science and Technology ${ }^{1}$ \\ and Department of Applied Chemistry and Biochemistry, Faculty of Engineering ${ }^{3}$, Kumamoto \\ University, 2-39-1 Kurokami, Kumamoto-City, Kumamoto 860-8555, Japan
}

${ }^{2}$ Department of Bioengineering, Yatsushiro National College of Technology, 2627 Hirayamashinmachi, Yatsushiro, Kumamoto 866-8501, Japan
Terephthalate is an aromatic compound used in the production of polyethylene terephthalate (PET) and is one of the top 50 most abundantly manufactured chemicals in the world (Savostianoff, 1990). A large amount of terephthalate is discharged during production of PET bottles and purification of terephthalic acid. Biological degradation of this compound has therefore been of interest in recent years.

Several micro-organisms have been shown to degrade terephthalate under aerobic conditions, including the Gram-positive bacteria Nocardia sp. strain DSM 43251 (Engelhardt et al., 1979), a Bacillus species (Karegoudar \& Pujar, 1985) and Dietzia sp. strain GS-1 (Sugimori et al., 2000). Among the Proteobacteria, Bordetella sp. strain K1,

Published online ahead of print on 20 June 2003 as DOI 10.1099/ ijs.0.02285-0.

Abbreviations: MLSS, mixed liquor suspended solids; PET, polyethylene terephthalate; TERDOS, terephthalate 1,2-dioxygenase system; TOC, total organic carbon.

The GenBank/EMBL/DDBJ accession number for the $16 \mathrm{~S}$ rRNA gene sequence of strain $T 7^{\top}$ is $\mathrm{AB} 075017$.
Pseudomonas sp. strain C4S (Kimura \& Ito, 2001) and two Comamonas testosteroni strains, T-2 (Schläfli et al., 1994) and YZW-D (Wang et al., 1995), have demonstrated the ability to degrade terephthalate.

Most of these micro-organisms have been reported to produce protocatechuate as an intermediate metabolite. The enzymic system responsible for the degradation of terephthalate has been thoroughly studied for C. testosteroni strain T-2. In that strain, terephthalate is degraded to protocatechuate by the terephthalate 1,2-dioxygenase system (TERDOS) (Schläfli et al., 1994) and protocatechuate is then metabolized via the meta cleavage pathway. Another C. testosteroni strain, YZW-D, reportedly uses a similar enzyme system for degradation of terephthalate (Wang et al., 1995).

Recently, a novel terephthalate-assimilating bacterium, designated strain $\mathrm{T7}^{\mathrm{T}}$, was isolated from the activated sludge of a domestic wastewater treatment plant. The isolate could utilize terephthalate as sole carbon and energy source. Based on 16S rRNA gene sequences and phylogenetic analyses, strain $\mathrm{T}^{\mathrm{T}}$ was placed in the genus Delftia; 
no members of this genus have previously demonstrated the ability to degrade terephthalate. Based on phenotypic and phylogenetic characterizations, it is suggested that strain $\mathrm{T}^{\mathrm{T}}$ constitutes a novel species, for which the name Delftia tsuruhatensis sp. nov. is proposed.

For enrichment of terephthalate-assimilating bacteria, a laboratory-scale activated sludge process was constructed. The aeration tank with a working volume of 31 was maintained at $30^{\circ} \mathrm{C}$ and air was supplied at $31 \mathrm{~min}^{-1}$. A 2.81 aliquot of activated sludge, which was provided by Kumamoto Hokubu sewage works (Tsuruhata, Kumamoto, Japan), was used as the initial reactor seed. The mixed liquor suspended solids (MLSS) concentration of the activated sludge, determined according to the Japanese standard method (Japanese Industrial Standards Committee, 1986), was $1620 \mathrm{mg} \mathrm{l}^{-1}$. Concentrations of total organic carbon (TOC) and inorganic carbon in the activated sludge supernatant, obtained after centrifugation at 10000 r.p.m. for $10 \mathrm{~min}$, were respectively $11 \cdot 3$ and $49 \cdot 1 \mathrm{mg} \mathrm{l}^{-1}$. The $\mathrm{pH}$ of the supernatant was $6 \cdot 86$. A basal salt medium supplemented with sodium terephthalate was fed continuously into the reactor at a rate of $1 \cdot 21 \mathrm{day}^{-1}$. The basal salt medium ( $\mathrm{pH} 7 \cdot 6$ ) contained the following $\left(1^{-1}\right): \mathrm{K}_{2} \mathrm{HPO}_{4}$, $3.48 \mathrm{~g} ; \mathrm{KH}_{2} \mathrm{PO}_{4}, 0.435 \mathrm{~g} ;\left(\mathrm{NH}_{4}\right)_{2} \mathrm{SO}_{4}, 1 \mathrm{~g} ; \mathrm{MgSO}_{4} .7 \mathrm{H}_{2} \mathrm{O}$, $0.2 \mathrm{~g} ; \mathrm{FeCl}_{3} \cdot 6 \mathrm{H}_{2} \mathrm{O}, 0.02 \mathrm{~g} ; \mathrm{NaCl}, 0 \cdot 1 \mathrm{~g}$; and $\mathrm{CaCl}_{2} \cdot 2 \mathrm{H}_{2} \mathrm{O}$, $0 \cdot 1 \mathrm{~g}$. Concentrations of sodium terephthalate were increased stepwise as follows: $200 \mathrm{mg} \mathrm{l}^{-1}$ for days 1-12; $500 \mathrm{mg} \mathrm{l}^{-1}$ for days 12-21; and $1000 \mathrm{mg} \mathrm{l}^{-1}$ for days 21-26. After 26 days continuous cultivation, the MLSS concentration of the culture broth in the reactor increased to $2800 \mathrm{mg} \mathrm{l}^{-1}$ and the concentrations of TOC and terephthalate in the reactor supernatant were respectively 15 and $<1 \mathrm{mg} \mathrm{l}^{-1}$. After 26 days continuous cultivation, the culture broth was used for isolation of terephthalateassimilating bacteria with the basal salt medium containing sodium terephthalate at a concentration of $500 \mathrm{mg} \mathrm{l}^{-1}$ supplemented with $1.5 \%$ agar. A $1 \mathrm{ml}$ portion of the culture broth was diluted with sterilized water, inoculated onto agar plates and incubated at $30{ }^{\circ} \mathrm{C}$. Following the first screening using an agar plate, positive colonies were cultivated in the basal salt medium containing sodium terephthalate at a concentration of $1000 \mathrm{mg} \mathrm{l}^{-1}$ at $30^{\circ} \mathrm{C}$ with continuous shaking. An isolate with a specific growth rate of $0.65 \mathrm{~h}^{-1}$ was obtained and designated strain $\mathrm{T} 7^{\mathrm{T}}$.

Strain $\mathrm{T}^{\mathrm{T}}$ was cultivated in liquid basal salt medium containing sodium terephthalate at a concentration of $15 \mathrm{mM}$ and the terephthalate in the culture broth was quantified according to Yumihara et al. (2002). The initial terephthalate concentration of $15 \mathrm{mM}$ was degraded completely within $12 \mathrm{~h}$ (Fig. 1a). TERDOS activity of the cell lysate of the isolate was determined using a Clarke-type oxygen electrode according to the method of Schläfli et al. (1994) (Fig. 1b). The result suggests that the isolate degrades terephthalate by TERDOS, as described previously for C. testosteroni strain T-2 (Schläfli et al., 1994).

To investigate the effect of substrate concentration on the

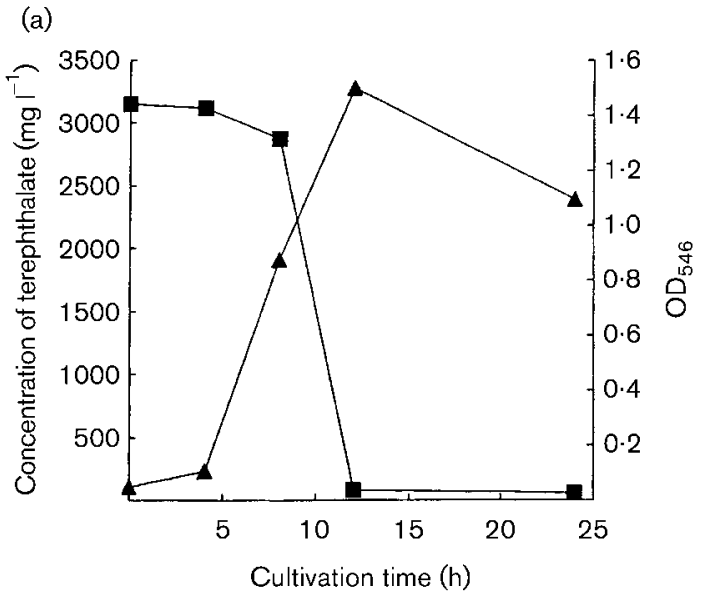

(b)

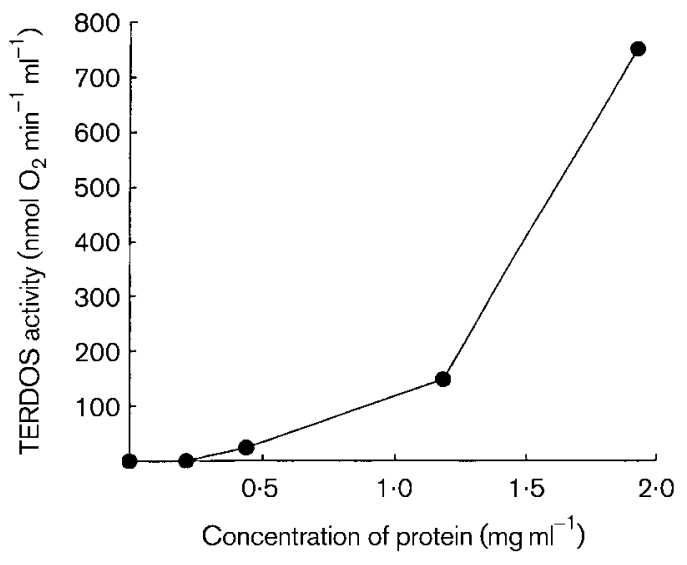

Fig. 1. (a) Utilization of terephthalate during growth of strain $\mathrm{Tr}^{\top}$ using basal salt medium containing sodium terephthalate (3000 $\left.\mathrm{mg} \mathrm{I}^{-1}\right)$ ( $\boldsymbol{\boldsymbol { \Xi }}$, terephthalate concentration; $\boldsymbol{\Lambda}, \mathrm{OD}_{546}$ ). (b) TERDOS activity (Schläfli et al., 1994) determined as $\mathrm{O}_{2}$ consumption in the cell lysate of strain $T 7^{\top}$ at protein concentrations of $0-2 \mathrm{mg} \mathrm{ml}^{-1}$.

respiration activity of the isolate, oxygen consumption rates in liquid basal salt medium were determined at sodium terephthalate levels between $0 \cdot 2$ and $10 \cdot 0 \mathrm{~g} \mathrm{l}^{-1}$, according to Morimura et al. (1998). With sodium terephthalate concentrations between 0.5 and $4.0 \mathrm{~g} \mathrm{l}^{-1}$, the oxygen consumption rate of the isolate was constant, at approximately $1.0 \mu \mathrm{min}^{-1}$. At sodium terephthalate concentrations below $0 \cdot 2 \mathrm{~g} \mathrm{l}^{-1}$ or between $6 \cdot 0$ and $10 \cdot 0 \mathrm{l}^{-1}$, a lower oxygen consumption rate of approximately $0 \cdot 8 \mu \mathrm{l} \mathrm{min}{ }^{-1}$ was observed. These results indicated that sodium terephthalate concentrations below $4 \cdot 0 \mathrm{~g}^{-1}$ had no inhibitory effect on respiration of the isolate.

Colonies of strain $\mathrm{T}^{\mathrm{T}}$ on nutrient broth plates were white. The cells did not produce water-soluble pigments or fluorescent pigments on King A or King B media. Cells appeared as slightly curved, short rods, $0 \cdot 7-1 \cdot 2 \times 2 \cdot 4-$ $4 \cdot 0 \mu \mathrm{m}$, and occurred singly or in pairs. They were motile. 
Gram-staining, preformed according to standard microbiological procedures (Gerhardt et al., 1994), was negative. The isolate accumulated poly- $\beta$-hydroxybutyrate, determined according to Stanier et al. (1966).

Strain $\mathrm{T}^{\mathrm{T}}$ grew at $10-40^{\circ} \mathrm{C}$, with optimum growth at $35^{\circ} \mathrm{C}$. No growth was detected after 10 days incubation at 7 or $42{ }^{\circ} \mathrm{C}$. A pH range of 5 to 9 was suitable for growth, with an optimum response at $\mathrm{pH} 7 \cdot 0$. The doubling time was approximately $1.06 \mathrm{~h}$ under optimum growth conditions in liquid basal salt medium containing $1000 \mathrm{mg}$ sodium terephthalate $1^{-1}$. The isolate could utilize the following compounds as sole energy and carbon sources under aerobic conditions: acetamide, $\beta$-alanine, citrate, $\mathrm{D}$-fructose, glycerol, isobutyrate, isophthalate, $\mathrm{D}(-)$-mannitol, maleate, malonate, phenylacetate, propionate, protocatechuate, terephthalate, D-tryptophan and L-tryptophan. The isolate could not utilize the following compounds: DL-3-aminobutyrate, $\mathrm{D}(+)$-arabitol, catechol, 2,3-dihydroxybenzoate, D-glucose, lactose, phthalate, L-serine, starch, sucrose, L-valine and $\mathrm{D}(+)$-xylose. Arginine dihydrolase, catalase, oxidase, lipase (Tween 80 hydrolysis) and urease activities, evaluated according to standard microbiological procedures (Gerhardt et al., 1994), were positive. The isolate performed meta cleavage of protocatechuate, determined according to Hugh \& Gilardi (1974). It could not denitrify, although the strain reduced nitrate to nitrite, as determined by the method of Stanier et al. (1966). The isolate could not hydrolyse starch. The isolate demonstrated no fermentative response, determined by the $\mathrm{O} / \mathrm{F}$ reaction (Hugh \& Leifson, 1953), using D-glucose, D(-)-fructose or terephthalate as substrates in OF basal medium (Difco).

Whole-cell fatty acids were extracted as methyl esters according to Komagata \& Suzuki (1987) and analysed by GC-MS. The most abundant fatty acids in strain $\mathrm{T}^{\mathrm{T}}$ were $\mathrm{C}_{16: 0}\left(33 \cdot 2 \%\right.$ total fatty acid methyl esters), $\mathrm{C}_{16: 1}(31 \cdot 1 \%)$ and $\mathrm{C}_{18: 1}(24.6 \%)$. In addition, significant amounts of cyclopropanoic acid $\left(\mathrm{C}_{17: 0} ; 3 \cdot 6 \%\right), 3-\mathrm{OH} \mathrm{C} \mathrm{C}_{10: 0}(2 \cdot 6 \%)$, $\mathrm{C}_{12: 0}(2 \cdot 0 \%), \mathrm{C}_{15: 0}(1 \cdot 6 \%)$ and $\mathrm{C}_{14: 0}(1 \cdot 3 \%)$ were detected. 3-OH $\mathrm{C}_{8: 0}$ was not detected. The DNA G+C content of strain $\mathrm{T}^{\mathrm{T}}$, measured according to Kamagata \& Mikami (1991), was $66 \cdot 2 \mathrm{~mol} \%$.

For determination of the 16S rRNA gene sequence of strain $\mathrm{T}^{\mathrm{T}}$, cells were lysed according to Hiraishi (1992). The 16S rDNA fragment was amplified by PCR (Hiraishi et al., 1994) using the following universal primers: forward, 5'-AGAGTTTGATCATGGCTCGA-3' (positions 8-27 of the Escherichia coli 16S rRNA gene); and reverse, 5' GGCTACCTTGTTACGACTT-3' (positions 1510-1492). The sequence of the amplified 16S rDNA fragment (1456 bp) was aligned with reference sequences using CLUSTAL X, version 1.8 (Thompson et al., 1997), and a phylogenetic tree was constructed using the neighbourjoining method (Saitou \& Nei, 1987) with the Kimura two-parameter model (Kimura, 1980) using MEGA version 2.1 (Kumar et al., 2001) (Fig. 2). Sequence similarities between strain $\mathrm{T7}^{\mathrm{T}}$ and relatives were as follows: Delftia sp.

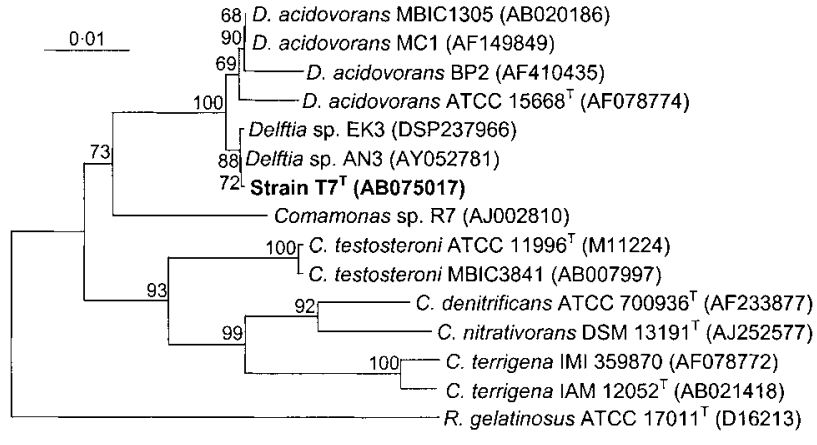

Fig. 2. Phylogenetic tree showing the relationship between strain $\mathrm{T7}^{\top}$ and related Delftia and Comomonas strains in the $\beta$-Proteobacteria based on 16S rDNA sequences. CLUSTAL $\mathrm{X}$ version 1.8 (Thompson et al., 1997) was used to align the sequences. The tree was constructed using the neighbourjoining method as outlined in the text. All gaps in the alignment were excluded; 1542 bases were compared. The sequence of Rubrivivax gelatinosus, family Comamonadaceae, $\beta$-Proteobacteria, was used to root the tree. Bootstrap probabilities (Felsenstein, 1985) are indicated at branch points. DDBJ/EMBL/GenBank accession numbers for reference strains are shown in parentheses. Bar, 1 nt substitution per 100 nt.

EK3, 99.8\%; Delftia sp. AN3, 99.7\%; Delftia acidovorans MBIC1305, 99.4\%; D. acidovorans MC1, 99.2\%; D. acidovorans $\mathrm{BP} 2,98 \cdot 7 \%$; D. acidovorans ATCC $15668^{\mathrm{T}}, 98 \cdot 6 \%$. The tree indicated that the isolate is apparently affiliated with the genus Delftia, which was introduced by the relocation of [Comamonas] acidovorans on the basis of phylogenetic and phenotypic analyses (Wen et al., 1999). The sequences of strains belonging to the genus Delftia form two distinct clusters, both with significant bootstrap values (69 and 88). One cluster, with a bootstrap value of 69 , includes the sequences of $D$. acidovorans strains ATCC $15688^{\mathrm{T}}, \mathrm{MBIC1} 1305, \mathrm{BP} 2$ and $\mathrm{MC} 1$. The sequence of strain $\mathrm{T}^{\mathrm{T}}$ and two Delftia strains, AN3 and EK3, were assigned to the other cluster (bootstrap value of 88 ). Therefore, the sequences of strains belonging to the genus Delftia can be divided in two distinct phylogenetic groups. DNA-DNA hybridization was performed according to Willems et al. (2001) at a hybridization temperature of $52{ }^{\circ} \mathrm{C}$ using total DNAs of strain $\mathrm{T}^{\mathrm{T}}$ and D. acidovorans ATCC $15668^{\mathrm{T}}$. Hybridization values were calculated as means of four duplicate hybridizations, with a mean standard deviation of $\pm 5 \cdot 2 \%$. As an internal control, reciprocal hybridizations were carried out. Using DNA from either strain $\mathrm{T}^{\mathrm{T}}$ or ATCC $15668^{\mathrm{T}}$ as the labelled DNA, hybridization values with DNA from ATCC $15668^{\mathrm{T}}$ or strain $\mathrm{T}^{\mathrm{T}}$ were respectively 68.7 and $68.6 \%$. The DNA-DNA hybridization value between the two strains was thus not significantly below the threshold value of $70 \%$ used for species delineation (Stackebrandt \& Goebel, 1994), and therefore does not provide a clear indication of the taxonomic placement of strain $\mathrm{T}^{\mathrm{T}}$ within the genus Delftia. 
Table 1. Features that can be used to differentiate between strain $T 7^{\top}$ and $D$. acidovorans

Abbreviations: +, present in all strains; -, absent in all strains; $\mathrm{d}$, variable reaction in different strains; NA, no data available. Data for D. acidovorans were taken from Wen et al. (1999) and Willems et al. (1991).

\begin{tabular}{|lcc|}
\hline Characteristic & Strain $\mathbf{T 7}^{\mathbf{T}}$ & D. acidovorans \\
\hline Cell size $(\mu \mathrm{m})$ & $0 \cdot 7-1 \cdot 2 \times 2 \cdot 4-4 \cdot 0$ & $0 \cdot 4-0 \cdot 8 \times 2 \cdot 5-4 \cdot 1$ \\
Carbon source used & & \\
for growth: & + & $\mathrm{d}$ \\
$\beta$-Alanine & - & $\mathrm{d}$ \\
3-Aminobutyrate & + & $\mathrm{d}$ \\
Glycerol & - & $\mathrm{d}$ \\
Phthalate & + & - \\
Terephthalate & + & - \\
Isophthalate & + & $\mathrm{NA}$ \\
Protocatechuate & $10: 0$ & $10: 0,8: 0$ \\
Major 3-OH acid(s) & $66 \cdot 2$ & $66 \cdot 6-68 \cdot 7$ \\
G + C content $(\operatorname{mol} \%)$ & & \\
\hline
\end{tabular}

Table 1 shows comparative phenotypic properties for strain $\mathrm{T}^{\mathrm{T}}$ and $D$. acidovorans. The isolate could not utilize 3 -aminobutyrate, whereas most $D$. acidovorans strains (20 of 21 strains tested), including the type strain, can utilize this substrate (Willems et al., 1991). 3-OH $\mathrm{C}_{8: 0}$, which is characteristic of members of the genus Delftia, was not detected among the cellular fatty acids, and the $\mathrm{G}+\mathrm{C}$ content of the isolate $(66.2 \mathrm{~mol} \%)$ was slightly lower than those of other strains belonging to the genus. On the basis of the phenotypic and phylogenetic analysis above and of the DNA-DNA hybridization value of around $70 \%$, it is proposed that strain $\mathrm{T}^{\mathrm{T}}$ should be classified as a novel species in the genus Delftia, for which the name Delftia tsuruhatensis sp. nov. is proposed.

\section{Description of Delftia tsuruhatensis sp. nov.}

Delftia tsuruhatensis (tsu.ru.ha.ten'sis. N.L. fem. adj. tsuruhatensis referring to Tsuruhata, Kumamoto Prefecture, Japan, where the type strain was isolated).

Gram-negative, motile, slightly curved, short rods $(0 \cdot 7-$ $1 \cdot 2 \times 2 \cdot 4-4 \cdot 0 \mu \mathrm{m})$. Cells occur individually or in pairs. Growth occurs between 10 and $40{ }^{\circ} \mathrm{C}$; optimum growth at $35^{\circ} \mathrm{C}$. Growth occurs at $\mathrm{pH} 5 \cdot 0-9 \cdot 0$; optimum growth at $\mathrm{pH} 7 \cdot 0$. Doubling time is approximately $1.06 \mathrm{~h}$ under optimum growth conditions. Non-fermentative. Positive for arginine dihydrolase, catalase, oxidase, lipase (Tween 80 hydrolysis) and urease activities and meta cleavage of protocatechuate. Denitrification ability is not observed, although nitrate reduction is found. Does not hydrolyse starch. The following compounds can be utilized as energy and carbon sources: acetamide, $\beta$-alanine, citrate, D-fructose, glycerol, isobutyrate, isophthalate, $\mathrm{D}(-)$-mannitol, maleate, malonate, phenylacetate, propionate, protocatechuate, terephthalate, D-tryptophan and L-tryptophan. The following compounds cannot be utilized: DL-3-aminobutyrate, $\mathrm{D}(+)$-arabitol, catechol, 2,3-dihydroxybenzoate, D-glucose, lactose, phthalate, L-serine, starch, sucrose, L-valine and $\mathrm{D}(+)$-xylose. The most abundant fatty acids are $\mathrm{C}_{16: 0}$, $\mathrm{C}_{16: 1}$ and $\mathrm{C}_{18: 1}$. Cyclopropanoic acid $\left(\mathrm{C}_{17: 0}\right), 3-\mathrm{OH} \mathrm{C}_{10: 0}$, $\mathrm{C}_{12: 0}, \mathrm{C}_{15: 0}$ and $\mathrm{C}_{14: 0}$ are detected in smaller amounts. $3-\mathrm{OH} \mathrm{C} \mathrm{C}_{8: 0}$ is not detected. The total DNA G $+\mathrm{C}$ content of the type strain is $66 \cdot 2 \mathrm{~mol} \%$.

The type strain, $\mathrm{T}^{\mathrm{T}}\left(=\mathrm{IFO} 16741^{\mathrm{T}}=\right.$ ATCC BAA-554 ${ }^{\mathrm{T}}$ ), was isolated from activated sludge in Tsuruhata, Kumamoto Prefecture, Japan.

\section{Acknowledgements}

We thank the following researchers for technical assistance: Syoutarou Iwasaki and Syusaku Sakai of Yatsushiro National College of Technology for 16S rDNA sequencing and Koki Saito of Kumamoto University for DNA-DNA hybridization.

\section{References}

Engelhardt, G., Rast, H. G. \& Wallnofer, P. R. (1979). Degradation of aromatic carboxylic acids by Nocardia spec. DSM 43251. FEMS Microbiol Lett 5, 245-251.

Felsenstein, J. (1985). Confidence limits on phylogenies: an approach using the bootstrap. Evolution 39, 783-791.

Gerhardt, P., Murray, R. G. E., Wood, W. A. \& Krieg, N. R. (1994). Methods for General and Molecular Bacteriology. Washington, DC: American Society for Microbiology.

Hiraishi, A. (1992). Direct automated sequencing of $16 \mathrm{~S}$ rDNA amplified by polymerase chain reaction from bacterial cultures without DNA purification. Lett Appl Microbiol 15, 210-213.

Hiraishi, A., Shin, Y. K., Ueda, Y. \& Sugiyama, J. (1994). Automated sequencing of PCR-amplified 16S rDNA on 'Hydrolink' gels. J Microbiol Methods 19, 145-154.

Hugh, R. \& Gilardi, G. L. (1974). Pseudomonas. In Manual of Clinical Microbiology, 2nd edn, p. 250. Edited by E. H. Lennett, E. H. Spaulding \& J. P. Truant. Washington, DC: American Society for Microbiology.

Hugh, R. \& Leifson, E. (1953). The taxonomic significance of fermentative versus oxidative metabolism of carbohydrates by various gram-negative bacteria. J Bacteriol 66, 24-26.

Japanese Industrial Standards Committee (1986). Testing methods for industrial wastewater, JISK0102-1986. Edited by H. Namiki. Tokyo: Japanese Standards Association.

Kamagata, Y. \& Mikami, E. (1991). Isolation and characterization of a novel thermophilic Methanosaeta strain. Int J Syst Bacteriol 41, 191-196.

Karegoudar, T. B. \& Pujar, B. G. (1985). Degradation of terephthalic acid by a Bacillus species. FEMS Microbiol Lett 30, 217-220.

Kimura, M. (1980). A simple method for estimating evolutionary rates of base substitutions through comparative studies of nucleotide sequences. J Mol Evol 16, 111-120.

Kimura, T. \& Ito, Y. (2001). Two bacterial mixed culture systems suitable for degrading terephthalate in wastewater. J Biosci Bioeng $\mathbf{9 1}$, 416-418.

Komagata, K. \& Suzuki, K. (1987). Lipid and cell-wall analysis in bacterial systematics. Methods Microbiol 19, 161-206. 
Kumar, S., Tamura, K., Jakobsen, I. B. \& Nei, M. (2001). MEGA2: molecular evolutionary genetics analysis software. Bioinformatics $\mathbf{1 7}$, 1244-1245.

Morimura, S., Hino, T. \& Kida, K. (1998). Storage of pitching yeast for production of whisky. J Inst Brew 104, 213-216.

Saitou, N. \& Nei, M. (1987). The neighbor-joining method: a new method for reconstructing phylogenetic trees. Mol Biol Evol 4, 406-425.

Savostianoff, D. (1990). TPA-DMT, confidence is coming back. Infect Chem 317, 193-201.

Schläfli, H. R., Weiss, M. A., Leisinger, T. \& Cook, A. M. (1994). Terephthalate 1,2-dioxygenase system from Comamonas testosteroni T-2: purification and some properties of the oxygenase component J Bacteriol 176, 6644-6652.

Stackebrandt, E. \& Goebel, B. M. (1994). Taxonomic note: a place for DNA-DNA reassociation and $16 \mathrm{~S}$ rRNA sequence analysis in the present species definition in bacteriology. Int J Syst Bacteriol 44, 846-849.

Stanier, R. Y., Palleroni, N. J. \& Doudoroff, M. (1966). The aerobic pseudomonads: a taxonomic study. J Gen Microbiol 43, 159-271.

Sugimori, D., Dake, T. \& Nakamura, S. (2000). Microbial degradation of disodium terephthalate by alkaliphilic Dietzia sp. strain GS-1. Biosci Biotechnol Biochem 64, 2709-2711.
Thompson, J. D., Gibson, T. J., Plewniak, F., Jeanmougin, F. \& Higgins, D. G. (1997). The CLUSTAL X windows interface: flexible strategies for multiple sequence alignment aided by quality analysis tools. Nucleic Acids Res 25, 4876-4882.

Wang, Y. Z., Zhou, Y. \& Zylstra, G. J. (1995). Molecular analysis of isophthalate and terephthalate degradation by Comamonas testosteroni YZW-D. Environ Health Prospect 103 (Suppl. 5), 9-12.

Wen, A., Fegan, M., Hayward, C., Chakraborty, S. \& Sly, L. I. (1999). Phylogenetic relationships among members of the Comamonadaceae, and description of Delftia acidovorans (den Dooren de Jong 1926 and Tamaoka et al. 1987) gen. nov., comb. nov. Int J Syst Bacteriol 49, 567-576.

Willems, A., Pot, B., Falsen, E., Vandamme, P., Gillis, M., Kersters, K. \& De Ley, J. (1991). Polyphasic taxonomic study of the emended genus Comamonas: relationship to Aquaspirillum aquaticum, E. Falsen group 10, and other clinical isolates. Int J Syst Bacteriol 41, 427-444.

Willems, A., Doignon-Bourcier, F., Goris, J., Coopman, R., de Lajudie, P., De Vos, P. \& Gillis, M. (2001). DNA-DNA hybridization study of Bradyrhizobium strains. Int $J$ Syst Evol Microbiol 51, 1315-1322.

Yumihara, K., Shigematsu, T., Hamada, K., Morimura, S. \& Kida, K. (2002). Anaerobic degradation of terephthalic acid and aniline by methanogenic consortia. Jpn J Water Treat Biol 38, 1-9. 